\title{
Mr Troutbeck as the Surgeon's Friend: The Coroner and the Doctors- An Edwardian Comedy
}

\author{
D ZUCK*
}

On 17 May 1902, at the age of 48, after a brief illness, pneumonia, Athelston Braxton Hicks, coroner for the South-Western District of London and the Kingston District of Surrey, died. ${ }^{1}$ He was the son of the eminent obstetrician and gynaecologist, consultant to Guy's and St Mary's Hospitals, whose name is still attached to the irregular painless uterine contractions that occur during pregnancy. ${ }^{2}$ Originally he had been intended for the medical profession, and had been a student at Guy's for several years. He had been called to the bar in 1875 , had been coroner for 17 years, and deputy before that. He had performed good public service in many ways. He had secured the regulation of the licensing of small boats, and of the sale of carbolic acid. He had campaigned against the evils of baby farming, and for fireguards in homes where there were small children. He was an authority on coroner's law, had been a very distinguished secretary and vicepresident of the Coroner's Society, and had served on the Joint Committee of the British Medical Association and the Coroner's Society. "Though a member of the legal profession", in the words of his obituarist, he had taken a great interest in medical questions affecting his office. Many coroners and doctors attended his funeral, and the Medical Defence Union was represented. Had the term carried its present-day connotation, the Association, which was campaigning for the appointment of medically qualified coroners, might well have described him as "one of us". His successor, Mr John Troutbeck, was quite a different kettle of fish.

\section{Coroners and the Law}

By the beginning of the nineteenth century the courts and the local justices had taken over so many of the functions of the coroner that his office seemed to be in terminal

*Dr D Zuck, ‘Craigower', St Andrew's Close, London
N12 8BA.

I am grateful to Dr John Burton, lately Hon.

Secretary and now President of the Coroner's

Society of England and Wales and HM Coroner for the Western Division of Greater London, for all the information derived from the Society's Minute Book; and to the staffs of the libraries of the Royal College of Surgeons of England, the Wellcome Institute, the House of Lords, the Guildhall Library, the British

\author{
Library Reading Room, and the Newspaper Library, \\ Colindale, for their assistance. \\ ${ }^{1}$ Death of Mr A Braxton Hicks, Br. med. J., \\ 1902, i: 1317; The Times 19 May 1902, p. 8; Lancet, \\ 1902, i: 1482 \\ 2 John Braxton Hicks, MD, FRCP, FRS, \\ (obituary), Lancet, 1897, ii: 692. He is also credited \\ with the invention of the procedure of combined \\ internal and external version that became widely \\ used for the management of breech presentations in \\ childbirth for almost a century.
}


decline; but changes in industrial and social conditions began to increase the range and importance of his inquiries. In the late 1820s Thomas Wakley launched a campaign in the Lancet to restrict the office to the medically qualified. ${ }^{3}$ In an editorial, Wakley stated that

The legal knowledge required of the Coroner may be comprised in a nutshell, and could be learned by a dunce within an hour ... but their ignorance of medical matters is a scandal to the criminal justice of the country ... no individual should be allowed to hold the office of Coroner, without having received a first-rate medical education.

As an example of a miscarriage of justice he cited the case of a woman convicted by a coroner's jury of killing a still-born child. A surgeon gave evidence that the child was still-born, but the coroner regarded it as his duty to make a public example of her for concealing the birth-hence a verdict of wilful murder- "thus making this woman KILL a still-born child".

The provision for the payment of medical witnesses, established in 1836, made pathological and toxicological investigations more readily available, and substantially increased the effectiveness of the coroner's inquiries. ${ }^{4}$ The founding of the Coroner's Society of England and Wales in 1846 provided mutual support, a corporate voice and a rise in status; and a number of factors combined to increase the significance of his work. An increasing interest in public health and epidemiology, the technological advances in manufacturing and transport, and the multiplication of ways of killing and being killed, broadened considerably the range and importance of the coroner's inquiries, and over the years provoked a mass of legislation that involved him in decisions with great practical implications. ${ }^{5}$ Much hinged on his correctly establishing the cause of death. But the situation of the coroner remained inadequate until he was freed from the control of the justices by the Local Government Act of 1888. This, while transferring to the newly created Borough Councils the power to appoint and agree coroners' salaries and expenses, made the coroners in the performance of their duties accountable only to the Lord Chancellor. Yet the position generally remained unsatisfactory. Some coroners had been in office for a great many years, ${ }^{6}$ and some local accords between coroners and general practitioners did not always work to the benefit of the public.

The law in relation to coroners was codified in the Coroners Act of $1887 .^{7}$ This laid down the circumstances in which inquests must be held, the provision for a jury, for the

3 'Necessity of a legal education to coroners', Lancet, 1827-8, i: 266-9. The campaign continued; see, for example, 'Address to the readers of The Lancet', Lancet, 1829-30, i: 3. For Wakley's activities as coroner for the Western District of Middlesex following his appointment in 1839 , see E Cawthorn, 'Thomas Wakley and the medical coronership-occupational death and the judicial process', Med. Hist., 1986, 30: 191-202.

${ }^{4}$ An Act to provide for the attendance and remuneration of medical witnesses at coroner's inquests ( $6 \& 7$ William IV c 89).

5 H H Pelling, 'Social change and the coronership', Med. Sci. Law, 1970, 10: 239-43.

${ }^{6}$ Coronership appears often to have brought with it the gift of longevity. In 1892 the London County Council petitioned the Lord Chancellor to remove $\mathrm{Mr}$ Carter, coroner for the Newington
District. He had been appointed in 1836, was now 86 years of age, and had been physically incapable of performing his duties for some while (Br. med. J., 1892, i: 515). At about the same time Mr William Churton, the well-known surgeon, held a jubilee court, to mark the completion of the fiftieth year from the date of his appointment as coroner $(\mathrm{Br}$. med J., 1892, i: 669-70).

7 Coroners Act 1887, 50 and 51 Vict. c. 71. The current authorities on the coroners are: $\mathrm{P}$ Matthews and $\mathrm{J} C$ Foreman, Jervis on the office and duties of coroners with forms and precedents, 10th ed. London, Sweet and Maxwell, 1986; and P Knapman and M J Powers, Thurston's coronership: the law and practice on coroners, 3rd ed., Chichester, Barry Rose, 1985. A history of the office of Coroner is contained in chs 1 and 2 of the latter. 


\section{Mr Troutbeck as the Surgeon's Friend}

calling of witnesses, and the paying of fees and expenses. But one paragraph, the first in Section 21 , came to play a very important part in later events:

Where it appears to the coroner that the deceased was attended at his death or during his last illness by any legally qualified medical practitioner, the coroner may summon such practitioner as a witness; but if it appears to the coroner that the deceased person was not attended at his death or during his last illness by any legally qualified medical practitioner, the coroner may summon any legally qualified medical practitioner who is at the time in actual practice in or near the place where the death happened, and any such medical witness as is summoned in pursuance of this section, may be asked to give evidence as to how, in his opinion, the deceased came to his death.

The next paragraph of Section 21 provides that the coroner may direct any such medical witness to make a post-mortem examination of the body.

But this, which was a consolidating Act only, was soon under attack from both the coroners and the medical profession. A Select Committee of the House of Commons reported in 1893 on a large number of deficiencies in the law as it applied to the certification and registration of deaths and burials. ${ }^{8}$ Under existing law, a registrar could register a death on production by a "qualified informant", for example a relative, of a medical certificate signed by a registered medical practitioner, or on the certificate of the findings of a coroner's jury. If neither of these documents was forthcoming, the registrar could accept the "qualified informant's" statement as to the cause of death, and such deaths were returned as uncertified. Thus the field was wide open for various forms of dishonesty. A general practitioner described how, on an early morning visit, he found a remarkable improvement in a patient who had appeared to be in extremis the previous day; but on arriving at his surgery he had found the relatives waiting for a death certificate. Bent on an insurance fraud, they told him that the patient had died during the night. The Select Committee recommended a number of measures which would counter such abuses as the concealment of unlawful killing, and insurance frauds. At the same time the coroners sought wider powers, in particular they wanted the doctors to be required to notify them of unnatural deaths; at that time this responsibility rested with the registrars. The Coroner's Society went so far as to suggest that failure to report such a death was a breach of Common Law, but this was contradicted by the Chief Clerk, Somerset House, and in an editorial in the British medical Journal. ${ }^{9}$ However, it is also apparent that instructions to registrars to refer uncertified deaths to the coroner were being opposed by local MPs, because of the distress that the delay in burial was causing the relatives.

The British Medical Association, continuing Wakley's endeavour of many years earlier, wanted to increase medical participation at all stages, and to raise the number of medically qualified coroners. In its Journal it regularly reported vacancies and invited doctors to apply. ${ }^{10}$ It advocated also the practice in the United States, whereby one of the

8 'Death certification and "information"', $\mathrm{Br}$. med. J., 1903, i: 1447-8.

${ }^{9}$ Br. med. J., 1899, ii: 1770 and 1750-1. The British Medical Association supported the recommendations of the Select Committee, particularly because they would reveal deaths of patients who had been attended by unqualified or "quack" practitioners.
10 'Coroners: medical or legal', Br. med. J., 1892, i: $669-70$, for example. Although there had been a gradual increase in the number of medical coroners, out of 331 in England 247 were lawyers. In the United States things were more advanced. In Franklin County, Nebraska, a young lady medical graduate aged 26 was appointed coroner $(\mathrm{Br}$. med. J., 1901, i: 1136). 
coroner's deputies was a physician who carried out a preliminary inquiry, advised on the need for an inquest, and suggested witnesses. ${ }^{11}$ The Association was incensed by the frequent failure to call medical evidence, and the resulting uselessness of the inquest. The index of the British medical Journal regularly contained an entry for inadequate, unnecessary, and useless inquests. Among examples was the verdict of a coroner's jury, "We find A.B. died from stone in the kidney, doubtless swallowed by deceased while lying in an unconscious state of drunkenness on a gravel path". 12 "Are medical men ever called to give evidence now?" commenced an editorial on coroners and inquests. ${ }^{13}$ At an inquest held at Salford the foreman of the jury suggested that medical evidence was desirable. "Yes," said the coroner, "but you see doctors are very chary of giving information unless they are paid for it."14

Relations between coroners and doctors in general were bad. Vindex, who in the British medical Journal asked whether, once the coroner's court was cleared for the jury to consider their verdict, he might freely express himself among the witnesses and the public who were waiting re-admittance as to the action of the coroner without fear of the consequences, was informed that the coroner had all the powers of a judge as to contempt of court, and that these continued as long as the court was sitting. Any language or conduct that might be considered contempt in the courtroom would be equally so in the precincts of the court; anyone likely to so offend should consider his ways and be wise. ${ }^{15}$ A less than wise general practitioner in Gateshead, who had briefly been taken into custody after an argument with the coroner, was advised to take his complaint to the Lord Chancellor; ${ }^{16}$ and a resident medical officer writing to complain about receiving insufficient notice that his presence would be required at an inquest was counselled ". . . not to fall out with the coroner if he can possibly avoid it". ${ }^{17}$

It has been suggested that the medical profession, as a result of the verdict in the KitsonPlayfair trial of 1896, was in a state of hypersensitivity, having found, "to its discomfort, that it was not left alone to police its duties, but was dictated to by its old rival, the legal profession". ${ }^{18}$ If that were so, it was soon to receive another unpleasant rebuff.

\section{The London County Council appoints Mr Troutbeck}

Fifteen candidates were short-listed for the post of coroner to the South-Western District made vacant by the death of Braxton Hicks. Among the doctors who applied were Dr Major Greenwood, who later became eminent as an epidemiologist and statistician, and Dr Ludwig Freyberger, a forensic pathologist. ${ }^{19}$ Among the laymen, all lawyers, this being a requirement for the holding of the office, was $\mathrm{Mr}$ John Troutbeck. The appointment was made during the course of a long and important meeting of the Public Control Department of the London County Council which resulted in the publication of an exhaustive report and key policy document on the subject of coroners, coroners' courts,

11 Br. med. J., 1890, ii: 637-8.

12 Br. med. J., 1899, ii: 585-6, quoted from Select Committee on Death Certificates, HMSO, 1893, p. 8 (see Brit. med. J., 1901, i: 191).

13 Br. med. J., 1894, i: 370-1.

14 Br. med. J., 1890, i: 105.

15 Br. med. J., 1898, ii: 1854.
${ }^{16} \mathrm{Br}$ med. J., 1900, i: 810-11.

17 Br. med. J., 1887, ii: 438.

18 A McLaren, 'Privileged communications: medical confidentiality in late Victorian Britain', Med. Hist., 1993, 37: 129-47.

${ }^{19} \mathrm{Br}$. med. J., 1902, i: 1362-3. 
and the conduct of inquests. ${ }^{20}$ The Council expressed much dissatisfaction with the existing system. Expenses had risen by some $£ 10,000$ over the past eight years, and it appeared that many thousands of pounds were being wasted on unnecessary inquests, because the coroners and their officers were being paid only if an inquest was held, and not for the expenses incurred in their preliminary enquiries. A move to a salaried service was proposed, with the amalgamation of districts so that whole-time coroners could be appointed with an income of about $£ 1,000$ per annum.

Hard things were said about the incompetence of the general practitioners who were performing the necropsies, and although they were defended by the Chairman, Sir William Collins, the eminent ophthalmic surgeon, ${ }^{21}$ it was recommended that a "well-qualified" pathologist be employed in each district, and that cases of a special nature be entrusted to a specially skilled pathologist. The Council reported that it was now providing proper coroners' courts, and the scandal of holding inquests in public houses had ceased. There was criticism of the tame army of jurymen who appeared to follow the coroner's officer about, rather with a view to obtain the florin than to further the ends of justice. ${ }^{22}$ Some twenty recommendations were set out, mainly in relation to the certification of death and the holding of inquests. It was suggested that medical investigators be appointed to inquire into all certified deaths, to conduct necropsies, and to advise the coroner whether an inquest was necessary, and who to call as witnesses. It was further recommended "that every case of death after a surgical operation should be reported to the coroner with a view to a preliminary inquiry, and, if necessary, the holding of an inquest". The recommendation that $\mathrm{Mr}$ Troutbeck be appointed to the South-Western District did not go unopposed; a motion to refer back was defeated, and his appointment, with a salary of $£ 7984 \mathrm{~s} 2 \mathrm{~d}$, was adopted by 58 votes to 35 .

John Troutbeck was born in the hamlet of Dacre, in Cumberland, the son of Dr Troutbeck, Precentor of Westminster Abbey, but was brought up, and lived all his adult life, at 6A Dean's Yard, adjacent to the Abbey. ${ }^{23} \mathrm{He}$ was educated at Westminster School and Queen's College, Oxford. He qualified as a solicitor in 1884. In 1888 he was appointed coroner for the City and Liberty of Westminster by the Dean and Chapter, in whose gift this appointment was; he had already been serving as deputy for some two years. ${ }^{24}$ His salary was $£ 500$ a year. The newly formed London County Council continued this appointment, and in 1893 it increased his salary to $£ 560 .^{25}$ As coroner he had already come to the public notice in 1891, when he had held an inquest in secret on the body of the 9th Duke of Bedford, who had reportedly died a natural death but had in fact

\footnotetext{
20 Report of the Public Control Department of the London County Council, The Times, 2 July, 1902, p. 4, and more fully in Br. med. J., 1902, ii: 72-3.

${ }^{21}$ For Sir William Collins, MP, see Who was who 1941-50, London, Adam and Charles Black, 1952, pp. 238-9.

22 The office of juryman was not without hazard, however. Jurymen were assembling to view a body in a loft over a byre at Newlands, County Kildare, when the weight of the twelfth caused the floor to give way, and all were precipitated onto the cattle and manure below. "the jury shouted and swore ... When released they presented a remarkable
}

appearance, being covered from head to foot with manure, while the odour exhaled from them was anything but pleasant." Lancet, 1902, i: 556.

${ }^{23}$ Who was who 1897-1915, London, A and C Black, 1935, p. 716.

${ }^{24}$ The Times, 10 July 1888 , p. 8. Troutbeck's predecessor, Mr Bedford, had held the post for 43 years.

25 Under the provision of the Coroners Act of 1860 , coroners' salaries were revised every five years, by agreement, on the basis of the number of inquests held, at thirty shillings per inquest $\mathrm{Br}$. med. J., 1891, ii: 874). 
committed suicide. ${ }^{26}$ Questions were asked in the House, but the coroner's right to hold an inquest in private was confirmed. From this it might be supposed that he had powerful friends, and was unlikely to rock the establishment boat. Seemingly assured of his position, he was liable to arouse strong emotions. He had had a brush with reporters, ${ }^{27}$ and had clashed also with the house surgeon at the Westminster Hospital over the accidental death of the Rt Hon W W B Beach, MP, who had been thrown out of a hansom cab in Parliament Street. The house surgeon made every effort to notify Troutbeck personally, but did not escape his wrath. ${ }^{28}$ On the other hand he had supported a club doctor against the accusation of neglect following the death of a child. ${ }^{29}$

So against some opposition, and with a certain reputation, Troutbeck was appointed to the South-Western District; ${ }^{30}$ and he came there with a mission. In his own words, and with a fairly explicit criticism of his predecessor, he regarded it as his duty, “ . . to restore in the South-Western District the independence and authority of the coroner ..."31 The London County Council had put the tools into his hand by requiring that post-mortem examinations be entrusted to a skilled pathologist except where the coroner was satisfied that the medical man connected with the case was competent. The Council circulated the London teaching hospitals with a request for nominations, and from the replies compiled a list of some dozen skilled pathologists from whom the coroners could choose. Troutbeck obviously decided early on that none of the local practitioners was a competent pathologist, and from the list he selected Dr Ludwig Freyberger to perform all his postmortem examinations. Freyberger had graduated MD in Vienna in 1889, and became an MRCP London in 1894. In the Medical Directory of 1904 he is described also as a barrister at law of the Middle Temple, toxicologist, pathologist selected for London inquests, and honorary physician to St Pancras and the Northern Dispensary. He was a member of many medical societies, including the British Medical Association, and the author of many publications. His Pocket formulary for the treatment of disease in children went through at least three editions, and was favourably reviewed. ${ }^{32} \mathrm{He}$ lived at 41 Regent's Park Road, NW1, and while this detail may seem insignificant, great play was subsequently made of it. How he came to be chosen by Troutbeck is a mystery, but possibly as a result of recommendation by the London County Council, or, since Freyberger had been practising as a forensic pathologist and toxicologist for several years, they may have become acquainted in the course of their duties.

\footnotetext{
${ }^{26}$ The Times, 15 January 1891, p. 9, 21 January, p. 6. According to the Duke's physician, Dr Gibbons, the Duke had passed away peacefully after a short acute illness; a cold had affected his lungs. The Press Association subsequently heard and reported that, because of the circumstances connected with death, the District Coroner, Mr Troutbeck, had held an inquest early in the morning on the day the body was cremated. The verdict returned by the jury was that His Grace, while suffering great pain and in a condition of extreme prostration, shot himselfevidently while he was, because of his condition, labouring under temporary insanity.

A dispute about an earlier inquest held in secret in Ipswich, on a drowned girl who was under suspicion that she was "enceinte", was brought to a head by a letter from the Lord Chancellor confirming the ruling
}

of the coroner, threatening the jurors with fines and penalties, and ultimately committing one of the reporters to prison for contempt (Br. med. J., 1887, i: 1394). Troutbeck, therefore, must have felt that he was on pretty firm ground. The secrecy that shrouded the true cause of the Duke's death was also commented on unfavourably in the Lancet, 1901, i: 213.

27 The Times, 7 October, 1891, p. 8.

${ }^{28}$ Lancet, 1901, ii: 1064-5.

29 Br. med. J., 1902, i: 1327.

30 Report of the Public Control Department of the London County Council, The Times, 2 July 1902, p. 4, and Br. med. J., 1902, ii: 72-3.

31 'The relation of coroners to the medical profession', Br. med. J. Supplement, 1904, ii: 53-4.

${ }^{32}$ Lancet, 1900, ii: 948 , and 1902, i: 383. 


\section{Mr Troutbeck as the Surgeon's Friend}

\section{The New Broom}

Within a matter of weeks the practitioners in the South-Western District began to feel the effects of the new regime. What they had previously regarded as their prerogative, suddenly dried up. Not only were they being deprived of post-mortems, they were no longer being summoned to inquests. With post-mortems at two guineas a time, and inquests at one guinea, this change in practice was making a significant impact both on the income of the local practitioners, and on their amour propre; so they attacked.

The opening shot of what proved to be a very long campaign was fired in the Lancet. ${ }^{33}$ Troutbeck had held an inquest on two infant siblings who had died after eating mussels. The attending general practitioner was asked to perform the post-mortem on the little boy, and Freyberger, who was described in newspaper reports as pathologist to the London County Council, on the little girl. The Lancet challenged this description, and considered that Dr Freyberger, had been placed in the distasteful "position of taking fees for work which a professional brother was in a fitter position to discharge than he was himself". It declared that the whole matter should be brought to the attention of the Coroner's Society.

This was followed by a letter complaining that Troutbeck had ordered Freyberger to perform post-mortem examinations, in the hospitals' own post-mortem rooms, on patients who had died in St Thomas's and Guy's Hospitals. Whatever the legality of the situation, this was a studied discourtesy to the hospital pathologists, and it also involved paying a fee for work that would otherwise be done for nothing. ${ }^{34}$ Worse still, in another letter, it was reported that Troutbeck, defending his actions, had stated during an inquest held on 10 December that medical men in general practice were not proper persons to make postmortem examinations. ${ }^{35}$ Troutbeck had expressed the greatest possible respect for the skill of the local doctors, who did their duty conscientiously, and he did not wish anything that he had said to cast any reflection on them, for he believed them to be devoted men who were doing their duty; but post-mortem examinations were most difficult operations, they required to be taught, and required great experience. He had been appointed to protect the public interest, and it was his emphatic duty to see that jurors obtained the best evidence. The writer of the letter, Dr Leonard McManus, member of Battersea Council and of the Wandsworth division of the British Medical Association, the local activist, absolutely denied Troutbeck's right to set himself up as an authority on the qualifications of medical

33 'The medical man, the coroner, and the pathologist', Lancet, 1902, ii: 1477. The Br. med. J., also, carried a number of letters and editorial comments adverse to Troutbeck, complaining, for example, that he had adopted "the very unusual course of handing over nearly all necropsies in the district to a stranger residing in Primrose Hill-Dr. Freyberger'. See Br. med. J., 1903, ii: 95 and 696, and 1904, i: 321-2, and 1904, ii: 1210.

34 Lancet, 1902, ii: 1574. The law regarding the payment of fees to medical witnesses at inquests was explained by the highly regarded Dr G Danford Thomas, HM Coroner for London (Br. med. J., 1897, i: 884 ). There had to be evidence of a pecuniary loss before a fee could be paid, and it was presumed that salaried hospital doctors would not suffer such a loss.
An appeal by an honorary medical officer at Walthamstow General Hospital for the payment of a fee for a post-mortem examination and attendance at an inquest failed before the Queen's Bench Division (Br. med. J., 1898, i: 1176).

${ }^{35}$ Lancet, 1902, ii: 1720 . Some doctors agreed. “G.P." suggested that all autopsies be done by one man specially selected for each district. "Very few of us, either general practitioners or consultants, are competent to make exhaustive post-mortem examinations" (Br. med. J., 1898, ii: 844). Braxton Hicks, however, pointed out that coroners were having great difficulty obtaining expert assistance, to the extent that an approach was being made to the Home Office (Br. med. J., 1898, ii: 1110). 
men. However excellent an official, he was only a layman; and since he had denied the local doctors the opportunity to make post-mortem examinations during the four months that he had been coroner, how could he form an opinion of their competence? He had taken the work away from very well qualified practitioners, and given it to Dr Ludwig Freyberger, "whose registrable qualifications in this country are of a very ordinary description ....".

\section{The Doctors Appeal}

The matter was discussed at a meeting of the London County Council on 16 December, when the Chairman of the Public Control Committee referred to its report of July $1 .^{36}$ The Committee had come to an arrangement with Dr Freyberger whereby he would make analyses in cases of suspected poisoning for an agreed fee. Finding that he was an experienced pathologist, and that he was prepared to take on cases requiring special pathological experience for the standard fee of 2 guineas, the Committee had suggested that coroners avail themselves of his services; but it agreed that to describe himself as pathologist to the London County Council was a misapprehension, and he had been asked not to do so in future. The Committee pointed out that Dr Freyberger had for seven years been pathologist to the Great Northern Central Hospital, had performed over 4,000 postmortem examinations, and had attended more than 1,200 inquests. He had been employed by the coroner in the South-Western District during the three months to November 30 to make 34 post-mortem examinations out of 249 inquests. The fees paid to him amounted to $£ 78$ 8s. The Committee did not contemplate that the medical attendant on the deceased would be superseded in ordinary cases, and it was evident from the figures that $\mathrm{Dr}$ Freyberger had only been employed in special cases.

But this emollient explanation of the operation of market forces did nothing to smooth the troubled waters, and on Friday, 2 January 1903, a special meeting of the South-West London Medical Society was held in the drill hall of the East Surrey Regiment, Clapham Junction. ${ }^{37}$ Eighty-three medical men attended. The president, Surgeon-Major $\mathbf{M}$ Robinson, IMS, reported that the Society had asked Mr Hempson of the Medical Defence Union to obtain counsel's opinion on the legality of Troutbeck's procedures in rélation to Section 21 of the Coroners Act; and Mr M Muir Mackenzie had advised that in his opinion "the practice adopted by $\mathrm{Mr}$ Troutbeck as detailed in the case is not in conformity with the statutory duties imposed on him". However he did not regard Troutbeck's conduct as amounting to a misdemeanour that would justify either an indictment or an application to the court to remove him, and his advice was to present the facts to the Lord Chancellor in an influentially signed memorial.

A lengthy discussion followed. It was agreed that the assistance of a special pathologist was welcome in suitable cases. But during the last few months Dr Freyberger had been called in for 16 out of 23 inquests in Battersea; and if such a high proportion were of a special nature, then Battersea must be a most extraordinary place. Dr McManus complained that Mr Troutbeck had not followed the ordinary ethics of decent society in dealing with the medical men of the district. Another speaker drew attention to $\mathrm{Dr}$ Freyberger's address, which could not possibly be included in the district of Battersea,

${ }^{36}$ Lancet, 1902, ii: 1717-18.

${ }^{37}$ Lancet, 1903, i: 126-7. 
unless the whole of London was to be absorbed into Battersea. Troutbeck was the only coroner who had adopted the system complained of, and Freyberger was much criticized for agreeing to undertake work as a specialist pathologist for an "ordinary" fee. ${ }^{38}$ Finally, it was agreed that the Council of the Society should approach the London County Council, and that a special fund should be set up, with an appeal for contributions from the profession in general, to defray any expenses.

\section{The Dust Flies}

In the meantime the Lancet had continued its campaign against Troutbeck, with an aggression and a relentlessness that its founder would have been proud of, far surpassing that of the British Medical Journal. It printed a letter from McManus describing how he had reported the death of an infant from overlying to which he had been called, and observed that although he had been making post-mortem examinations in the district for 18 years, this case, which was a very ordinary one, had been referred to Dr Freyberger. He was utterly at a loss to understand why a special pathologist had been called. ${ }^{39}$ An editorial annotation reported the inquest on a child where the attending general practitioner had refused to supply any information to the coroner's officer. ${ }^{40} \mathrm{~A}$ postmortem and an inquest had therefore been necessary, and Troutbeck had said that the doctor, by withholding information, had put the County to the expense of a perfectly useless inquest. The Lancet thought it was time that Mr Troutbeck ceased representing to juries that the whole agitation against his introduction of Dr Freyberger to Battersea was due to fee-hunger. Troutbeck, in return, used the opportunity of the address to his juries to

\footnotetext{
38 McManus's complaint that Freyberger was prepared to work for an "ordinary" fee was just one more example of the quarrel between general practitioners and specialists over competition, fee cutting, and patient-stealing. Attempts to raise the income, and hence the status, of general practitioners, were being undermined by specialists who were prepared to charge little more than the family doctors themselves. If a patient could get a Harley Street opinion for almost the same price, there was little doubt where he would spend his money. General practitioners, strongly supported by the British Medical Association, were trying to persuade specialists to raise their fees, so that they could then raise their own. Although the problem had previously been confined to clinicians, now one of the ancillary specialties was offering a threat to an important source of income. Hence McManus's complaint against Freyberger that, although he claimed to be a specialist, he was prepared to accept an "ordinary" fee. For a superb exposition of the problems of income and status that concerned doctors during the second half of the nineteenth century, see M J Peterson, The medical profession in mid-Victorian London, Berkeley, University of California Press, 1978, especially pp. 224-9.

${ }^{39}$ Lancet, 1903, i: 201 . In the early part of this
}

century some 1,500 infant deaths each year were attributed to "overlaying" or "overlying". These were infants, usually younger than nine months, who had been taken into bed with an adult, and were found dead from apparent suffocation. A major publication on this condition, first reported in the middle of the last century, was by coroner Dr W Wynn Westcott, 'The overlying of infants', Br. med. J., 1903, ii: 1208-9. During 1905 there were 403 inquests in London alone on children found dead in bed with their parents (Br. med. J., 1906, ii: 736), Section 13 of the Children's Act of 1908 deemed that such a death, if in bed with a person over the age of 16 who was under the influence of drink, constituted neglect, and hence was a criminal offence. The agitations of the Temperance Movement, particularly active during the 1890 s, may well have influenced this legislation. That the large majority of these deaths were due to other causes (today's "cot deaths"), was shown by the Birmingham coroner Dr W H Davison, 'Accidental infant suffocation', Br. med. J., 1945, ii: 251-2. It appears that Troutbeck and Freyberger were concerned, out of consideration for the parents, not to attribute a death to overlying if another cause, such as bronchitis, could be found; McManus disagreed.

${ }^{40}$ Lancet, 1903, i: 275. 


\section{Zuck}

answer his critics. ${ }^{41}$ During an inquest reported in the St. James's Gazette of 10 January 1903, and in the Lancet, he had set out the position of the London County Council, and had continued, "It is perfectly clear that a great many medical men in the neighbourhood thought that the law was made for the good of medical practitioners and not for the good of the country; but that was a position that he would not for one moment recognise". He was bound to carry out his duty without fear, favour, or affection, and to the best of his skill and knowledge, and did not mean to change from his purpose on account of any suggestion "that Battersea money should be spent on Battersea doctors". An annotation in the Lancet, while pointing out that Troutbeck was merely carrying out the policies of the London County Council, the legality of which it questioned, regretted the unworthy innuendo of greediness on the part of the Battersea doctors. ${ }^{42}$

A further long annotation accompanied by a lúke-warm editorial comment reported Troutbeck's elaboration on his approach to his official duties. He had started with a history of the coroner's office. ${ }^{43}$ In the early days, during the reign of Edward I, there were no doctors, and the juries had had to do the medical examination themselves; but things had advanced. He had discussed the subject with leaders of the medical profession, and there was no doubt that the opinion of the London County Council was the correct one. To say that the nearest medical practitioner was the best person to make the post-mortem was as reasonable as to say that in a trial the nearest barrister would make the best judge. It was important to do justice to the public, to parents who might be unjustly accused of overlying and suffocating a child. There was no intention to offer a slight to medical practitioners. "I take a man as I find him, doing the work I know he does."

\section{Support for Troutbeck}

But Troutbeck's policies received support from a most authoritative medical source, $\mathrm{Dr}$ $\mathrm{H}$ H Littlejohn, Lecturer in Medical Jurisprudence in the University of Edinburgh. In a paper read before the Medico-Legal Society in London he addressed three questions: in what cases should a post-mortem examination be performed? who should perform it? and what procedures and methods should be followed $?^{44}$ As regards his second question, he thought it

41 Lancet, 1903, i: 187.

42 Ibid. However there is clear evidence in their letters that some practitioners saw a post-mortem examination or an inquest as their only means of receiving any payment for their attention to indigent patients who had died, or to whom they had been called after death. For example, J R N, complaining about the inquest on a man who had died of a fracture of the skull, wrote, "I spent half a day trephining and raising the depressed bone, and was not called by the coroner to give evidence" (Br. med. $J ., 1893$, i: 208). So there was much resentment when what they regarded as their rightful dues started to go into the distant pocket of one who had not rendered the deceased any service at all. According to Peterson, op. cit., note 38 above, pp. 214-15, it was not unusual for a London practitioner to earn only $£ 3$ a week; so fees were important. 'Philanthropist', for example, wrote in to inquire

whether, in the event of the patient dying and an inquest being held, the coroner could censure him or lecture him if he had declined to go to a night call without being paid his fee. The reply was that although such censure would not be justified, it was within a coroner's power to censure for any conduct he might personally disapprove of (Br. med. J., 1902, i: 119). (To put the monetary aspect into a personal perspective, by 1945 the attendance fee for the medical witness at an inquest had only gone up to one and a half guineas. Of this, custom and selfinterest required that one shilling and sixpence be left on the table for the coroner's officer; but the remaining thirty shillings was one and a half times the weekly salary of a teaching hospital houseman, and a very welcome addition to one's income).

43 Lancet, 1903, i: 342-3.

44 H H Littlejohn, 'Medico-legal post-mortem examinations', Lancet, 1903, i: 862-6. 


\section{Mr Troutbeck as the Surgeon's Friend}

ludicrous, if it were not such a serious matter, to reflect that in this advanced age and in an enlightened and humane country the law still permits any medical practitioner to be summoned to make a post-mortem examination without any regard to his knowledge, his previous experience, or his capacity to fill the duty thus imposed on him.

Cases of a most serious nature, where a prolonged term of imprisonment or a capital sentence might be entailed, were being left in the hands of medical men who were neither competent from experience or knowledge to decide the questions at issue. He continued with an example that concerned the possible transmission of infection by a midwife. He had asked permission to attend the post-mortem examination, and was greatly surprised when the medical man instructed by the coroner informed him that he had never made one before-“a fact which was easily discernible from his methods of operation-and yet a woman was committed for trial at the assizes on a charge of manslaughter on this gentleman's evidence". He had no hesitation in saying that the majority of general practitioners were not qualified to undertake such an important and responsible duty, and it should not be thrust upon them. He continued with a lengthy criticism of the teaching of forensic medicine in England, largely presented as book-learning, by teachers with no practical experience. Teaching in Scotland was much superior, being entrusted to those in constant medico-legal practice. ${ }^{45}$ Then there was a considerable difference between an ordinary pathological examination of a dead body, and one conducted by a forensic pathologist, and this formed the third part of his paper. In passing he referred to the infant deaths from food poisoning, and supported the action of the coroner in seeking the report of an independent pathologist.

There seems to be a tendency to regard inquest fees as a reliable source of income and perquisite of a practice, transferable with its sale and impersonal to the owner of the practice, hence the outcry when a coroner, in the exercise of his discretion and plain duty, calls in outside aid. The position in many places appears to be-fees first and justice second; but such an attitude is wholly indefensible.

But Littlejohn's views were challenged in a long leading article. ${ }^{46}$ The Lancet could not agree with him regarding the training and experience of medical practitioners in general. It reiterated the opinion that in the great majority of cases the medical practitioner who had attended the deceased during life should perform the post-mortem.

Both the Lancet and the British Medical Journal reported on meetings of the Public Control Committee with deputations from St Thomas's Hospital and the South-West London Medical Society. ${ }^{47}$ The Committee had also seen Mr Troutbeck, and had fully considered the matter, and had recommended that where a medical practitioner had been in attendance, and it appeared to the coroner that his evidence would be material to the elucidation of the case, then he should be invited to attend the post-mortem and give evidence at the inquest, although a pathologist might have been employed. The Lancet was very glad to hear that this had been suggested to Mr Troutbeck. It implied that the coroner's officer would no longer be sent to get medical information, and that evidence

45 As late as the 1930 s it was only the determination of the non-medical members of the appointments committee that ensured that an eminent forensic pathologist was selected for the chair at a Midlands university. The other applicants were a general surgeon and a lecturer in public health, neither of whom had any practical experience whatever in medico-legal pathology.

46 Lancet, 1903, i: 901-2.

47 Lancet, 1903, i: 674; Br. med. J., 1903, i: 582, a rather fuller account. 


\section{Zuck}

would be given upon subpoena and for the statutory fee. Further, it was hoped that when special pathologists were needed, they would be chosen from those of recognized standing within the profession.

However, although coroners were appointed and paid by the Borough Councils, they were answerable only to the Lord Chancellor; and in a letter of $10 \mathrm{March}$, with a confused table of cases attached, McManus claimed that nothing had changed, and that in fact since the deputation to the London County Council more post-mortem examinations had been given to Freyberger than before. ${ }^{48}$

\section{Appeal to the Lord Chancellor}

So on 12 May 1903 a joint Deputation of representatives of the British Medical Association, the South-West London Medical Society, the Medical Defence Union, and the Capital and Counties Medical Protection Society as it was then known, waited on the Lord Chancellor, the Earl of Halsbury. ${ }^{49}$ Lord Halsbury was at the time in his eightieth year. He was born in 1823, and died in 1921 at the age of 98 . He had been Lord Chancellor, with two short breaks with changes of government, since 1885 . He was a pillar of the establishment, a man of enormous influence, and leader of the "diehard" peers who opposed the Parliament Bill of 1911.50 From the obsequious nature of the correspondence one sees that the doctors, influential signatories though they might have been, went very much cap in hand.

The memorandum that the deputation laid before him alleged that $\mathrm{Mr}$ Troutbeck, in a wide variety of instances, had departed from the usual and recognized procedure adopted by coroners, in that he dispensed with the evidence of the medical practitioner who had been in attendance at the time of death, restricted the medical evidence that was placed before the Jury, and had "introduced the somewhat novel plan of calling in outside medical testimony" in that he regularly called upon a medical practitioner who had no knowledge of the case to conduct the post-mortem examination. The deputation recognized that the London County Council, which was now vested with the responsibility for coroners, required that post-mortem examinations be entrusted to a skilled pathologist in all cases except those where the coroner was satisfied that the medical man connected with the case was competent to perform a trustworthy post-mortem examination. But whereas Mr Braxton Hicks had never felt the need for outside assistance, Mr Troutbeck constantly did so, employing a Dr Freyberger, not known to any of the representative bodies as a pathologist, in some 65 per cent of all inquests. The deputation did not dispute that cases requiring special knowledge did occur, but not frequently; they constituted perhaps 1 per cent of all inquests. As examples of what Mr Troutbeck regarded as special cases, but the deputation did not, they cited a judicial hanging in Wandsworth Goal, and a man who had been killed by a train cutting off his head.

48 Lancet, 1903, i: 758; Br. med. J., 1903, i: 643. McManus wrote to both journals. In the same issue of the Br. med. J., Dr Major Greenwood wrote to ask whether a general practitioner invited to observe a post-mortem would be paid a fee.
${ }^{49} \mathrm{Br}$. med. J., 1903, i: 1178-9.

$50 \mathrm{~S}$ Hynes, The Edwardian turn of mind, Princeton University Press, 1968, and London, Pimlico Press, 1991. 


\section{Mr Troutbeck as the Surgeon's Friend}

Furthermore Mr Troutbeck had recently adopted the practice of only informally notifying the patient's practitioner that a post-mortem would be held, without officially directing him to take any part therein; and also, during certain enquiries, he had drawn a parallel between Dr Freyberger and the local medical men, not to the advantage of the latter. The coroner had no right to express an opinion on the qualifications of medical men.

Sir Victor Horsley, a pugnacious and plain-speaking debater, whose rudeness to his equals was said to be exceeded only by his courtesy to his inferiors, spoke on behalf of the British Medical Association. ${ }^{51}$ It is probably no exaggeration to describe Horsley at this time as the darling of a large part of the profession. He was a high-flier who had conducted important research into myxoedema, rabies, and the localization of function in the brain, and was a pioneer of neurosurgery, yet he still found sufficient time and energy to play a leading role in the affairs of the profession. He said that in his opinion the evidence presented was sufficient to establish the charge that $\mathrm{Mr}$ Troutbeck had contravened the Coroners Act, by his disregard of Section 21, which directed him to call the medical man who had attended the person before death, or had been called in at the time of death. Further, he had contravened the Act in that he had in a large number of cases set aside the clinical evidence. Also he had gone so far as to state that general practitioners were not trained in pathology and were not competent to perform pathological investigations in ordinary cases. This the British Medical Association strongly contested. Medical men were thoroughly trained in pathology, and in the vast majority of cases the medical man who had attended the patient was perfectly competent to perform the postmortem examination.

The Lord Chancellor, in his reply, said that he had listened to them, as was his duty, but he could express no opinion adverse to Mr Troutbeck until he had heard what he had to say. However, he could not agree that Section 21 of the Coroners Act had been contravened, since this was advisory rather than an absolute statutory requirement. Taking the examples that the deputation had advanced, it was absurd to say that the person who had last attended them should be called to the inquest of either a judicial hanging or a man who had been killed in a railway accident. Those things must be left, as so many things must be left, to the person conducting the enquiry. As regards what the coroner had said about this or that medical man, it would hardly be appropriate for him to enquire into that, or to express an opinion until he knew the facts. It might be that the medical man might have incurred the coroner's animadversions properly. In conclusion, he said that he agreed about the importance of the matter, and that "he would make a communication to the coroner, and if the coroner gave him an explanation it should be conveyed to them". The deputation, hearing the words but not the message, thanked him and withdrew.

The Lord Chancellor wrote to Mr Troutbeck on 18 May asking for his comments on the British Medical Association's memorandum. Troutbeck replied at length on 26 May to the observations of what he called the two Medical Societies and the two Limited Liability Companies. He contradicted all their accusations, and particularly those of Sir Victor Horsley; and he submitted that the Lord Chancellor's approval of the Deputation's

51 J B Lyons, The citizen surgeon: a biography of Sir Victor Horsley, London, Dawnay, 1966, pp. 104-5, etc.; and also, S Paget, Sir Victor Horsley,
London, Constable, 1919, where it is more necessary to read between the lines. 


\section{Zuck}

demands would "establish a peculiar and privileged position for a special class against the general interests of the community". 52

This reply was communicated, without comment, by the Lord Chancellor's office on 3 June 1903, to the British Medical Association, who clearly found it to be unsatisfactory, and resolved to supply the Lord Chancellor with full details of all the cases proving the charges against Troutbeck. These were sent on 27 July $1903 .{ }^{53}$

\section{The Association compiles a Dossier}

The British Medical Association's lengthy letter dissected Troubeck's answer line by line, and was accompanied by a dossier of some fifty or more cases in which the coroner was held to have transgressed the rules. Among these was one that kept on cropping up as the dispute progressed. This was that of a child, alleged by the general practitioner to have died of measles, but because Freyberger had not seen the body until after the rash had faded, he had reported it as a death from blood poisoning.

Additional documentary evidence was submitted on 17 May of the following year, 1904; and on 1 July, in preparation for the Annual Representative Meeting, at which the subject was to be discussed, the British Medical Association wrote again to the Lord Chancellor, pointing out that matters relating to Troutbeck had been brought to his notice on three occasions, and enquiring whether the Association might expect any communication from him. ${ }^{54}$ At the same time, it resolved to send a letter to the Prime Minister if a reply was not received within seven days. No reply having materialized, the Association wrote to Mr Balfour on 25 July, setting out the case against Troutbeck, and asking him to consider whether it was his province as head of His Majesty's Government to direct the attention of the Lord Chancellor to the matter. No reply or acknowledgement was received, but, no doubt quite fortuitously, on 29 July a letter was received from the Lord Chancellor's office, stating that "the Lord Chancellor had not found it possible to give time for a minute examination of all the facts and arguments" that had been placed before him, and that while his present impression was not in favour of the coroner's practice, he did not think a case had been made for the exercise of the only jurisdiction that he possessed, which was to remove him from office for misconduct. Nevertheless the Association submitted more evidence on 5 January 1905, with a further request for a judgement.

\section{A Question in the House}

At the same time the South-West London Medical Society arranged for a question to be asked in the House of Commons. Sir Henry Kimber, MP, asked the Home Secretary in how many inquests held during the past year had coroners called in specialists to perform post-mortem examinations in place of the medical men specified in Section 21 of the Coroners Act, and whether he would take steps to insure uniform practice in this matter. ${ }^{55}$ Mr Akers-Douglas replied that he had no material from which numbers could be supplied,

\footnotetext{
52 'The relation of coroners to the medical profession', Br. med. J. Supplement, 1904, ii: 53.

${ }^{53}$ Br. med. J. Supplement, 1904, ii: 53-61.
}

\footnotetext{
54 Br. med. J. Supplement, 1904, ii: 125.

55 'Medical notes in Parliament', Br. med. J., 1904, ii: 199.
} 


\section{Mr Troutbeck as the Surgeon's Friend}

and no power to require coroners to follow a uniform practice. In a letter in a subsequent issue of the British Medical Journal the Hon. Secretary of the South-West Society, Dr Donald F Shearer, complained that Sir Henry had had great difficulty in getting his question on the order paper, and that a request for further information had been edited out first. ${ }^{56} \mathrm{He}$ also complained that the Attorney-General had refused a request for the High Court of Justice to hold an inquiry. It appeared that the simplest course for the Government was to let Troutbeck go his own sweet way.

The Lancet continued its campaign. ${ }^{57}$ It questioned Troutbeck's preference for Freyberger's evidence as against that of the house officer from St Thomas's Hospital, ${ }^{58}$ and wondered why a special pathologist was needed where a child had died after being run over by an "electric landaulette" whose driver had admitted the fact, ${ }^{59}$ and for two murderers, Albert and Alfred Stratton, hanged in Wandsworth Gaol. ${ }^{60}$ It commented that the numerous complaints received about Troutbeck had featured in the annual report of the Medical Defence Union, ${ }^{61}$ and reported on a further question asked in Parliament. ${ }^{62}$ It noted that during 1904 Troutbeck had held 926 inquests, and engaged Freyberger in 450 of them, from which it calculated that he had received $£ 945$ in fees, and frankly it did not think his services were worth the money. ${ }^{63}$ A letter of strong support for Troutbeck from Lieut-Col J H Tull Walsh, IMS, based on his experiences in India, where he had held the appointment of coroner's surgeon, was dismissed with the editorial comment that the two situations were in no way similar. ${ }^{64}$

That the local doctors were far from inactive in recruiting lay support is clear from the following report in the Sun newspaper. ${ }^{65}$

An inquest was held at the Lambeth Coroner's Court today by Mr. Troutbeck concerning the death of a 2-month-old child from suffocation whilst sleeping in bed with its parents. Dr. Reed, who had been called in when the child was found dead gave evidence, and Dr. Ludwig Freyberger, pathologist, was called to state the cause of death.

A Juryman said: I should like to ask, Mr. Coroner, why a second doctor was called in in this case? The Coroner: Because I choose.

The Juryman: I think it is most unfair.

The Coroner: It has nothing to do with you, sir.

The Juryman: As a ratepayer, I think it has everything to do with me.

The Coroner: I can't discuss it. Resume your seat please. It is a question of policy that lies with me. The Foreman (to the Coroner): No doubt some cases you have to deal with require special skill, but this was a perfectly straightforward case, and in this, as in other cases, I think the doctors who devote their lives to the service of the people should be called.

The Jury: Hear, hear.

The Coroner said that certain cases needed careful and skilful examination.

56 Br. med. J., 1904, ii: 353.

57 The Lancet for the twelve months from July 1904 indexes some thirty items under "Troutbeck". The researcher's heart sinks ...

58 Lancet, 1904, ii: 961-2; see also Br. med. J., 1904, ii: 769 .

${ }^{59}$ Lancet, 1905, i: 1084.

60 Lancet, 1905, i: 1455.

61 Lancet, 1905, i: 1517.

62 Lancet, 1905, i: 1551.
63 Lancet, 1905, i: 1624.

64 Lancet, 1905, i: 1674-5.

65 'A jury's protest', Br. med. J., 1905, i: 223.

The Br. med. J. records other instances up and down the country of juries questioning the absence of medical evidence or failure to perform a postmortem examination. In reply to one such, the coroner had said, "I should not like any of my relatives to be cut up and mauled by doctors" ( $\mathrm{Br}$. med. J., 1899, i: 1304). 
In readiness for the next Annual Representative Meeting, a further letter was sent to the Prime Minister on 6 March 1905, to which no reply was received, ${ }^{66}$ and when, on 26 July, the Chairman, Sir Victor Horsley, presented his report, ${ }^{67}$ he expressed the view that this was a discourtesy which he did not think the Prime Minister would inflict on any other profession. As for the Lord Chancellor, printed evidence was continually being sent to him, but he preferred to do nothing, and in this attitude he was supported apparently by the Prime Minister. That was the position as regards the Government; but as regards the County Council, the Association was approaching the Auditor, with a view to the payments to the so-called pathologists being surcharged. Replying to a reminder from the floor of a prior proposal that the Association should approach the Crown itself, it appears that approaches had been made, because the Meeting was advised that it was understood that the Crown objected to being approached on constitutional matters.

There followed a debate on the "conduct" or "inaction" or "failure to reply" of the Prime Minister. ${ }^{68}$ The proposer, Captain Booth-Clarkson, speaking in exceedingly great sorrow, since he had been a member of one of the most important Conservative clubs in England for over twenty years, urged his audience to forget, on this occasion, whether they were Whigs or Tories, and remember that they were medical men and members of the British Medical Association. As far as he personally was concerned, he felt very much as Lord Palmerston did once when he burst in upon his colleagues in Downing Street and said, "If you fellows are going to put up with this, I am damned if I do". Mr Balfour was defended by a general practitioner who had known him since he was first elected, and by another who was a neighbour, and who "was sure he was the last man in the world to act knowingly with discourtesy"; but nevertheless a condemnatory resolution was passed nem con. Strengthened by this, a meeting was arranged with one of Mr Balfour's private secretaries, following which a letter was received from the Prime Minister's office, dated 28 July 1905, regretting that the Association had not received the acknowledgement to their letter, but pointing out that the subject was exclusively the concern of the Lord Chancellor. ${ }^{69}$ Clearly the Prime Minister had no intention of tangling with the Leader of the House of Lords.

In the meantime, the Ethical Committee of the Association reported a resolution ${ }^{70}$ disapproving the action of the specially skilled pathologists who had agreed to make postmortem examinations and give evidence at special inquest cases for the ordinary fee of two guineas, and proposed that a conference be held with the Medical Boards of the London teaching hospitals with a view to the withdrawal of the London County Council's list of pathologists. The proposer of the resolution, Dr McManus, while disclaiming any personal feeling against the coroner himself, described his approach as most autocratic, offensive, narrow-minded, and bigoted. Troutbeck had stated in open court in the presence of McManus, that he did not consider that general practitioners in South-West London were men fit to make a post-mortem examination. That statement could not be accepted as authoritative from any layman. "But when so-called special pathologists tumbled over each other to accept the post of special pathologists at ordinary fees, that gave some colour

66 Br. med. J., 1905, ii: 120.

$67 \mathrm{Br}$. med. J. Supplement, 1905, ii: 146-8.

68 'The inaction of the government in respect of the coroner of South-West London', Br. med. J.

Supplement, 1905, ii: 141-2.

\footnotetext{
${ }^{69} \mathrm{Br}$. med. J. Supplement, 1905, ii: 147-8.

70 'Pathologists in coroners' courts', Br. med. J. Supplement, 1905, ii: 142-3.
} 


\section{Mr Troutbeck as the Surgeon's Friend}

to the coroner's statement". Furthermore, Battersea Borough Council was inviting all medical men to make their post-mortem examinations in the new post-mortem rooms, built at a cost of $£ 5,000$, and second to none in London; and the coroner had instructed the mortuary keeper under pain of commitment for contempt of court, not to admit any medical man to that mortuary while his own pathologist was making a post-mortem examination. This meant that the general practitioner was denied the opportunity of verifying the statements of the pathologist. Then, managing to include an uncomplimentary reference to Freyberger without naming him, he asked, "Was it too much to ask the so-called special pathologists, the majority of whom were gentlemen, public-school men, and men of honour, to abandon this indefensible position which they were taking up?" It appeared that it was, because it was reported that a communication to the special pathologists, several of whom, including Freyberger of course, were members of the Association, had not been favourably received; and it was decided to leave individual Divisions to deal with the matter.

The following week, 5 August, Troutbeck, the Lord Chancellor, and the Prime Minister, were strongly attacked in a long editorial in the British Medical Journal. ${ }^{71}$ The Lord Chancellor had not found time to "read a few pages of printed matter". No doubt his office made great calls on his time and energy;

but Lord Halsbury possesses an amount of energy and vigour, physical and mental, which may well be the envy of men thirty years his junior, and we venture to think that he might and ought to have found time to adjudicate in a matter involving the life and honour of the subjects of this realm.

Then there was the Prime Minister:

everyone will be anxious to acquit Mr. Balfour of any intentional discourtesy. Probably the syllogism which passed through his mind was: This is business to which the Lord Chancellor ought to attend; the Lord Chancellor attends to his business; therefore this business will be done. Q.E.D. Unfortunately there was something wrong with Mr. Balfour's middle: the Lord Chancellor cannot find time to attend to his business . . .

The profession was now resentful of this inaction by the officers of state; apparently no remedy was to be obtained from the present Ministry. "But", it concluded darkly, "Ministries change, and a general election is at hand." This stimulated a flurry of correspondence in the Journal, during which the proposal that the whole profession should vote to unseat the present government in the forthcoming election was countered by the question, when had the radicals ever done anything for the doctors? It had taken the profession two years to realize how monumental a brush-off it had been dealt.

\section{A Second Front}

As already indicated, the British Medical Association, frustrated, was preparing an attack on another front. As a rate-payer it had made an application to the Local Government Auditor, questioning the legality of certain payments made by the London County Council through Mr Troutbeck. The inquiry commenced on 31 October, and after an adjournment concluded on 28 November. The report in the British Medical Journal ran

71 'The government and the profession', Br. med. J., 1905, ii: 291-2. 
to some seventeen full pages. ${ }^{72}$ Both the British Medical Association and the London County Council were represented by learned counsel. Essentially the British Medical Association's case centred on Section 21 of the Coroners Act, and the argument was whether the local practitioners had the right to be called either to perform post-mortem examinations or to give evidence at inquests in uncomplicated cases, for if so, all the payments made to Dr Freyberger were illegal. Much harmless fun was had by all. As regards, for example, the man found decapitated on the South-Western Railway, Counsel for the British Medical Association submitted that from one's knowledge of English history, there was not much doubt, when a man was decapitated, as to the cause of death; so was it really necessary for Dr Freyberger to be brought down from Regent's Park Road to say that what this man died of was that his head was found on one side of the line and his body on the other? But Freyberger was not the only pathologist complained against; in one inquest a Dr Richardson was referred to. The famous case of measles was raised again. Then there was the question whether Freyberger could in any way be described as being in actual practice near the place of death. Counsel for the London County Council submitted that in so far as he carried out post-mortem examinations there, he could be so described, whereupon his adversary commented that the practice of medical men was among the living, not among the dead. If Dr Freyberger was said to be in practice in Battersea, then all his patients, fortunately or unfortunately for them, were dead before he got there.

What was spurring the British Medical Association on will be seen from the figures submitted by its Counsel. During the year in question $£ 1,098$ had been paid to Freyberger, and including the previous ten months, a total of $£ 1,767$. Under such attacks by the Association of which he was himself a member, poor Dr Freyberger could afford to cry all the way to the bank. In fact during that year he had been able to move to a much more imposing residence near Regent's Park, and, to make himself more readily available, had been one of the first to install a telephone, his number being 8 Hampstead.

The report of the somewhat bemused District Auditor was issued on 11 January $1906 .{ }^{73}$ It took up less than one column in the British Medical Journal. It expressed sympathy with those members of the profession affected by Mr Troutbeck's procedure, but had to conclude that the payments had to be allowed. Some six months later the Auditor issued a slightly longer statement giving his reasons for the conclusion he had reached. ${ }^{74}$ It boiled down to the fact that the coroner had filled in the forms properly, so there was nothing to be done about it; and clearly some influential representations had been made to him, because he now qualified his sympathy by the expression of his conviction that both the Public Control Committee of the Council, and the coroner, had been solely influenced by a desire to ascertain effectually the cause of death in cases where inquests were held, and to act generally in the public interest.

\section{The Quest for Reform}

Troutbeck continued to advocate reform, speaking at meetings of the Queen's Square Club and the Medico-Legal Society. In a lecture to the former he suggested that a medical

72 Br. med. J. Supplement, 1905, ii: 264-73 and 312-19.
73 Br. med. J. Supplement, 1906, i: 16.

$74 \mathrm{Br}$. med. J. Supplement, 1906, ii: 205. 


\section{Mr Troutbeck as the Surgeon's Friend}

investigator be attached to each coroner's court, to inspect all dead bodies, assent or dissent to a certificate, order a post-mortem, and report to the coroner. ${ }^{75}$ As examples of inadequate diagnoses he cited a doctor who wished to certify that death, where a dagger had been found in the heart, was due to cardiac disease, and another who had certified death as due to "a mass of disease". The Lancet thought there was a great deal in favour of independent examination, but hoped that caution and tact would be used, and that a not too drastic measure would be passed to bring improvement in death registration. The British Medical Journal was less charitable, dismissing Troutbeck's proposals as rubbish. ${ }^{76}$ In the Medico-Legal Society, Sir William Collins, MP, supported Troutbeck's view that all medically qualified men were not equally competent pathologists. ${ }^{77}$ Things had improved greatly in London during the past decade, he said; but while chairman of the Public Control Committee he had led two deputations to the then Lord Chancellor, Lord Halsbury, and on each occasion they had been met with a fatal non possumus. $\mathrm{Mr}$ Bernard Shaw, speaking as a layman, supported the highly qualified disinterested specialists as contrasted with the general practitioners, and to awaken public interest to the dangers revealed he mentioned the recently published Handbook for Murderers.

After the set-back suffered by the British Medical Association an undeclared truce seems to have been observed, for things fell quiet for about a year, although the general friction continued, and the correspondence columns of the British Medical Journal carried a number of complaints about the conduct of various coroners up and down the country, mainly in relation to the non-payment of fees. ${ }^{78}$

\section{Anaesthesia and Surgery in the Coroner's Court}

\section{The Immunity of Surgeons}

After the third recorded death associated with general anaesthesia, which was at Grantham, on 9 March 1847, it had become the practice to hold an inquest into all such cases. But with surgical mishaps the picture was quite different. As late as 1901 the Coroner's Society of England and Wales received this enquiry from one of its members:

75 'Mr Troutbeck upon the law affecting inquests and burials', Lancet, 1906, i, 843.

76 'The reform of the coroner', Br. med. J., 1906, i: 760 .

77 Lancet, 1906, i: 1832-3.

78 The Lancet managed to praise Troutbeck's “admirable remarks" about quacks (1906, ii: 135), and reported also his criticisms of the newly built Battersea mortuary, which lacked provision for the preservation of bodies, some of which were presented in an advanced stage of decomposition, and which lacked also a toxicological laboratory (1906, ii: 658). But the main complaints, which originated from various parts of the country, related to the non-payment of fees. The difficulty commonly arose when two doctors were called to give evidence at an inquest and the coroner decided that he would pay only one fee (Br. med. J., 1906, i: 237-8, and 1907, i: 1163 , for example). Doctors who had been called to view a body by a policeman were advised to apply for payment to the Chief of the County Constabulary (Br. med. J., 1909, i: 638). The annual report of the Public Control Department of the London County Council for 1905 disclosed that of the disbursements of the twelve London districts the lowest was the Eastern, at $£ 16 \mathrm{~s} 0 \mathrm{~d}$ per inquest, and the highest the South-Western, Troutbeck's, at $£ 35 \mathrm{~s}$ 2d (Br. med. J., 1906, ii: 736). By now Troutbeck had achieved the distinction of having his own entry in the index of the Br. med. J.-i.e. Coroner, see Troutbeck, and of The Times, in addition to the Lancet. For general complaints against Coroners, see, for example: 'No inquest', Br. med. J., 1907, i: 116. 


\section{Zuck}

I have always been in doubt whether Inquests should be held in cases of operation. I should be glad if you will let me know whether you think shock following abdominal operation is a matter which ought to be inquired into or not.

And he mentioned a certificate in which the cause of death was given as cancer of the sigmoid flexure, intestinal obstruction, shock following abdominal operation.

The Secretary of the Society, Mr A Braxton Hicks, replied as follows: "The question of holding Inquests in deaths arising after, or out of, an operation has been discussed by the Society on several occasions." He went on to say that while some few took the view that an operation was an injury, so an inquest should be held, it had been the general opinion for many years that it would be unwise to do so where the operation had been for the relief of disease. In the case of an operation following an injury, of course an inquest must be held to ascertain the cause of the injury; and he continued:

It may be in both these class of cases an anaesthetic was administered and that death was directly due to the effects of such an administration, and in such cases it has generally been held advisable to hold an Inquest to ascertain if ordinary precautions were taken in such administrations.

He concluded:

In cases like the one you mention it would greatly hamper medical men performing operations if they thought that in case of death an Inquest would be held. I think it is a wise plan not to hold Inquests in these cases, unless the relatives or friends of any person complain of the action of the medical men, or allege any negligence. ${ }^{79}$

This suspicion of the anaesthetic has to be seen against the background of a steep rise in the reported number of anaesthetic-related deaths during the last decade of the nineteenth century; and that then, as now, the law did not per se require anyone giving an anaesthetic to have any sort of qualification. This question was very much in the forefront of medical attention during the first decade of the twentieth century.

As the law stands at present, the administration of anaesthetics is under no regulation. Although a man cannot sell a glass of beer to another without a licence, he may drug that other person to his heart's content, without let or hindrance from the law. Apart from any criminal intent, a bone-setter, or a beauty doctor, or a quack of any kind is as much at liberty to administer an anaesthetic to his patient for the purpose of an operation as a qualified medical practitioner. ${ }^{80}$

The major anaesthetics textbooks drew attention to this anomaly also: "As the law now stands, any person may administer any kind of anaesthetic for any surgical, medical, obstetrical, or other purpose". ${ }^{81}$ And more dramatically:

${ }^{79}$ Minute Book of the Coroner's Society of England and Wales, pp. 291-2. But not everyone was in favour of this immunity. "M.B., M.A." wrote to ask why inquests were always held after chloroform deaths but not after operations. If the jury were competent to judge the anaesthetic, why should not they not also decide whether the surgeon had applied his ligature properly? Holding such inquests created a prejudice against anaesthetics $(B r$. med. J., 1888, ii: 1088$)$.

\footnotetext{
${ }^{80}$ Coroner's Committee-report of inquiry into the question of deaths resulting from the administration of anaesthetics, $\mathrm{Cd}$. 5111, London, HMSO, 1910, p. 4.

${ }^{81}$ D Cotes-Preedy, 'The medico-legal aspects of surgical anaesthesia', in F W Hewitt, Anaesthetics and their administration, 4th ed., London, Macmillan, 1912, pp. 641-55.
} 


\section{Mr Troutbeck as the Surgeon's Friend}

Who, in the eye of the law, is qualified to administer an anaesthetic? . . . nurses, students, butlers, coachmen, dispensers, and various unqualified persons have been frequently permitted to give the anaesthetic, or, as the phrase is, "keep it going", while the surgeon, besides operating, is supposed to exercise a general supervision. ${ }^{82}$

Official action had extended only so far as to require registrars to report all anaesthetic deaths to the coroner. ${ }^{83}$ So the Coroner's Society was rightly alert to the need to hold an inquest in any case where the administration of an anaesthetic might have contributed to the cause of death, and Troutbeck was merely conforming to its recommendations when, early in 1908, he held an inquest on a patient who had died on the table in the Westminster Hospital at the end of an operation for the removal of carcinomatous glands of neck. ${ }^{84}$ The surgeon, Walter G Spencer, reported the death immediately to the coroner, Mr Troutbeck, and both he and the anaesthetist, Dr Bourns, were subpoenaed to attend the inquest. ${ }^{85}$ In a lengthy account in the British Medical Journal, Spencer reported how he had complained to the jury that the removal of the body from the Westminster Hospital to the public mortuary, and the postponement of the post-mortem examination from 10 a.m. to 5 p.m., had prevented anyone from the hospital being present; and that the incomplete examination conducted by Dr Freyberger had prevented the immediate cause of death, suspected to have been an air embolism, from being determined. Had the examination been conducted by the hospital pathologist it would have been made within twenty-four, not seventy-two hours after death, it would have been much more thorough, and it might have provided more information about an obscure case of cancer. But this was beyond Dr Freyberger's interest; he had stopped short of the very goal which Mr Troutbeck more than once had told the jury was his aim.

Troutbeck, in his address to the jury, accepted that the Pathology Department of the Westminster Hospital was well equipped and that the staff was fully competent; but the members of the Surgical and Pathological Departments were colleagues in the same institution, and therefore it must be assumed, on behalf of the public, that collusion between them to obscure the immediate cause of death was likely to happen. Hence it was essential that the body be removed for an independent examination. This is a remarkable

82 D W Buxton, Anaesthetics: their uses and their administration, 5th ed., London, H K Lewis, 1914 , p. 457.

${ }^{83} \mathrm{Br}$. med. J., 1897, i: 1519. Attempts to introduce legislation were unsuccessful. In 1909 a Bill to restrict those who could administer anaesthetics to registered medical practitioners or dentists who could produce evidence of having received practical instruction, and to prohibit a death certificate being given in the case of a death under an anaesthetic failed to reach the Statute Book. 'Medical notes in Parliament', Br. med. J., 1909, ii: 44.

84 “. . . inquests should be held in all deaths occurring whilst under the influence of an anaesthetic, irrespective of whether the friends and those specially concerned in the administration of the anaesthetic and the operation were satisfied in every way", Minute book of the Coroner's Society of England and Wales, 1907, pp. 352-3.
85 W G Spencer, 'Report and remarks on an inquest held by Mr. J. Troutbeck at the coroner's court, Horseferry Road, Westminster, on March 28th', Br. med. J., 1908, i: 843-4. Spencer was the principal speaker on the subject of 'Coroners and medical men' at a meeting of the Medical Society of London in March 1909. He supported the idea that post-mortem examinations should be made by special pathologists, but "the pathologist employed must be the genuine article". By this he appeared to mean, on the staff of a teaching hospital. There was also the question of who was the right and proper practitioner to be called to give evidence. On this the coroner should listen to the advice of the pathologist, rather than to tittle-tattle and hearsay picked up by the coroner's officer (Br. med. J., 1909, i: 786). 


\section{Zuck}

statement for the coroner to have made, and reveals his extreme distrust of the medical profession, a distrust apparently not widely shared by his colleagues.

\section{Troutbeck crosses the Rubicon}

We have seen that in 1901 the Coroner's Society had advised against holding an inquest where the surgery, not the anaesthetic, was thought to have accelerated the death; and this advice was reiterated in $1907 .{ }^{86}$ So Troutbeck was breaking new ground when, on 3 June 1908, he held an inquest on Gertrude Helen Muirhead, a music teacher, who had died in the Bolinbroke Hospital after an operation for the removal of a tumour from the brain. This inquest was reported in The Times and the Daily Telegraph the following day. ${ }^{87}$ The surgeon, Sir Victor Horsley, had been called as a witness, and had said that the case was such an ordinary one that he could not understand why an inquest was being held. The coroner replied that owing to the advance of surgery, operations were much more frequent than they used to be, and since they were clearly to some extent a cause of the deaths that resulted, they came within the Coroners Act of 1887 , which made inquests imperative in such cases. Sir Victor replied, somewhat unwisely, that if that were the case 10,000 inquests would have to be held every year.

In his address to the jury, Troutbeck said that it was the opinion of all coroners that if a death had been accelerated by an operation it could not be said to be a natural death, and so came within the third section of the Coroners Act, which provided that an inquest must be held when death was due to causes either unnatural or violent. ${ }^{88} \mathrm{~A}$ death that had been accelerated by an operation could not possibly be said to be a natural death. He knew that a considerable proportion of deaths which undoubtedly were in great part due to surgical operations were never reported to the coroner. This was because the registrars were not fully aware of the requirements of the Act of Parliament. The result was that throughout the country we were in a state of complete ignorance as to what proportion of deaths were accelerated by surgical operations. He had learned from the Bolingbroke Hospital alone that 14 such deaths had occurred, and in 30 others there had been an operation in connection with the terminal illness. Whether those operations had accelerated death one could not tell, but a serious condition of things stood revealed, and he did not intend to let the matter stand. It was extremely important from the public point of view, and the coroner represented the public. They could not leave these things to any profession, however honoured or skilled. In the case under consideration, he directed that a verdict of

\footnotetext{
86 Disagreeing with the recommendation of the London County Council (note 20), in 1907 the Coroner's Society had reiterated its advice of 1901 (note 79), "where the patient had recovered from the effects of the anaesthesia, and the death was due to a necessary operation or the disease for which the operation was performed, an inquest is not required, provided always that there is no allegation of neglect, serious rumours or presumed want of skill on the part of the operator, or that the friends of the deceased do not request an inquiry for their satisfaction" (Minute book of the Coroner's Society of England and Wales, 1907, p. 352).
}

\footnotetext{
87 The Times, 4 June 1908, p. 14; Daily Telegraph, 4 June 1908, p. 7.

88 I have not been able to find any evidence that the coroners as a body had had a change of heart, but see note 106 . Troutbeck, however, directed his attention to the questions of whether it was a necessary operation, and whether there had been any want of skill on the part of the operator, and in this his conduct fell within the Society's guidelines. The same criteria are applied today.
} 


\section{Mr Troutbeck as the Surgeon's Friend}

"accidental death" would be a proper one if the jury were satisfied that the operation was justifiable and that all due care had been taken. Such a verdict was returned.

\section{Battle is Joined}

Two days later, 6 June, The Times carried a long letter from Horsley. ${ }^{89}$ It began by again questioning the grounds upon which the inquest had been held. The case was a perfectly simple one, and no manner of doubt existed as to the cause of death, which had been due to heart failure resulting from pressure on the nervous system by a cerebellar tumour. But not only did Mr Troutbeck hold an inquest, and hold it in his special way; he had put forward in his address to the jury a claim for coroners' jurisdiction in general which, if universally carried into effect would put an end to the practices of medicine as well as surgery, besides involving the ratepayers in an enormous cost in coroners' fees and other expenses. Then there was the question of whether Mr Troutbeck was competent to reach the vast and highly technical decision of whether the death had been accelerated by the medical practitioner in charge of the case.

Horsley continued with a re-statement of the British Medical Association's complaints about Troutbeck, and an account of the 1903 approach to the Lord Chancellor. He repeated the accusation about the celebrated case of measles, and in passing attacked both the Lord Chancellor and Dr Freyberger; and he concluded by pointing out that the responsibilities that every operating surgeon had to bear at the time were heavy enough. "If to these is to be added the prospect that in every case which terminates in death the propriety of his technical methods will be publicly adjudicated upon by incompetent persons, his position will be an intolerable one."

Horsley was supported by a leading article in the Lancet $^{90}$ After summarizing the many complaints against Troutbeck, it attacked him for going against the recommendations of the Coroner's Society by holding an inquest on a patient who had died three days after the operation, and it concluded that his latest move "seems to have been instigated by a desire to wound the medical profession". This opinion was echoed in a letter from Dr Major Greenwood..$^{91}$ He strongly disapproved of Troutbeck's action; it would be a fatal bar to all progressive surgery.

This was followed on 9 June by a letter in The Times from Dr Shearer, Hon. Secretary of the South-West London Medical Society, which contained the startling information that between May 1903 and February 1905, whereas the other seven coroners in London had, between all of them, 46 cases requiring the attendance of a special pathologist, $\mathrm{Mr}$ Troutbeck had found it necessary to call in Dr Freyberger 816 times. ${ }^{92}$ Shearer went on to assert that Troutbeck's decision to hold this particular inquest could only be attributed to his specific animus against the medical profession. Year by year hundreds of death certificates had been registered in Troutbeck's district in which an operation had been set down among the causes of death. Yet till he could attack Sir Victor Horsley, who took part in the agitation against him some years ago, Mr Troutbeck had let them pass. But now, to the hazards of a surgical operation, "a new and disgusting horror had been added"-that

89 The Times, 6 June 1908, p. 12.

90 Lancet, 1908, i: 1703-4.
91 Lancet, 1908, i: 1714.

92 The Times, 9 June 1908, p. 6. 


\section{Zuck}

in the event of death following the operation, a post-mortem examination at the public mortuary and a subsequent public inquiry would take place.

Both these letters were printed also in the British Medical Journal of that week, with a promise, which never materialized, to reprint in the next issue the reply from Troutbeck that was published in The Times on 10 June. ${ }^{93}$ Troutbeck, who was himself a Daily Telegraph man, said that his attention had been called to Horsley's letter. While, he continued, the letter hardly merited serious notice, it contained certain mis-statements of fact, which might as well be corrected since they were misleading to the public. Horsley's description of the cause of death was incomplete. At the post-mortem examination another cerebellar tumour, the size of a chestnut, had been found, the existence of which had not been suspected. It had not been removed, so the operation had been incomplete. Then various statements had been put into Troutbeck's mouth that he had not made; and in the death from measles, the facts were again wrongly stated. The death had been from erysipelas following infection of a vaccination. A medical man had been called in only after death, and had said he could not certify, as he had never attended the case. The socalled rash had not faded. The case had been investigated by the Local Government Board, who had come to the same conclusion as the jury.

So much for personal matters. To come to the real point, if Sir Victor Horsley was right, that inquests on all deaths caused by operation would amount to 10,000 each year in London alone, then none of those deaths were being brought to the attention of the coroners. The objection to publicity in Horsley's letter was significant; but why should it exist? Was it because some operations would never be undertaken at all if there was a possibility that the surgeon would have to explain publicly why he had operated and why his patient had died? A Select Committee of the House of Commons had concluded that our system of death certification was so imperfect that we did not know what was happening.

The power of dealing with other people's lives by means of surgical operations should not be allowed to continue uncontrolled and without some provision being made in the interests of the public. The people have a right to know the full cause of death in those cases where their relatives have had the misfortune to die after an operation.

Troutbeck's implication that Horsley may have been practising experimental surgery was countered in a letter from Dr M J Biggs, Gertrude Muirhead's general practitioner. ${ }^{94}$ The patient and her relatives had been consulted fully by Horsley before the operation, he wrote, and had been entirely satisfied with his conduct of the case. He himself had looked after the patient for a number of years, yet he had not been called to give evidence at the inquest.

Two days later, on 12 June, The Times carried another letter from Horsley, ${ }^{95}$ a letter from McManus, ${ }^{96}$ and a long leading article, all attacking Troutbeck and his practices. Horsley denied that a second tumour had been found. It had been a false capsule, purposely left behind at the operation, as he had explained to Freyberger. He wrote also about the expected quality of life of the patient; had she survived for some months without operation, she would have been totally blind, vomiting, racked with headache and totally

93 The Times, 10 June 1908, p. 8.
94 Ibid.
95 The Times, 12 June 1908, p. 13.

96 Ibid., p. 20. 


\section{Mr Troutbeck as the Surgeon's Friend}

bedridden. As to the implication that he had been practising experimental or irresponsible surgery, he included a letter from the family which confirmed that full consultation had taken place before the operation, that informed consent had been given, and that there was complete satisfaction with his management of the case.

McManus cited yet again his examples of Troutbeck's failings. He had reported two clear cases of infant death by overlying, and both had been misdiagnosed by the pathologist. He strongly supported Horsley. "Surely it is high time for the Lord Chancellor to intervene."

The leading article leaned very heavily toward the stand taken by the British Medical Association. ${ }^{97}$ It commented on the correspondence to date, and referred to Horsley's latest letter, which had also contained the accusation that the decision to hold an inquest at the last moment had caused the funeral to be postponed, thus inflicting great pain and inconvenience on the relatives. It continued, that at the inquest Troutbeck had stated that he had been informed that the operation had been the cause of death, but he had neither named nor called his informant. The relatives had not been dissatisfied and had not communicated with the coroner. Neither had he called the private practitioner who had attended the patient during the last three years of her life; and the evidence of the pathologist appeared to have been immaterial to the verdict. "Now," it thundered, "we have no hesitation in saying that this sort of thing will never do. It is intolerable, and justly intolerable, to the whole medical profession." It continued, "it may be that our system of death certification is imperfect, but if so, then Mr. Troutbeck does not seem to be going the right way to improve it. His peculiar mode of operation casts a most unworthy slur on the whole medical profession"; and, citing and echoing McManus, it concluded, "Surely it is high time for the Lord Chancellor to intervene".

As might be expected, that week's British Medical Journal carried another long editorial, going over the whole ground again. ${ }^{98}$ The Lancet, too, weighed in with another leading article. Troutbeck, it reported, had given interviews to the Daily Telegraph and the Standard, setting out his view that it was impossible at present to say whether deaths following operations were or were not the direct result of the surgical treatment, and even that it was possible that many of the operations were unnecessary. "Does this mean", it continued, "that Mr. Troutbeck thinks that, with the assistance of Dr. Freyberger, he can review all the circumstances which determine a patient to submit to operation and which decide for a surgeon what his procedure will be? Even with Dr. Freyberger's support, how could he be in a position to tell a coroner's jury whether an operation had been necessary, and whether it had been properly performed? It was hoped that the Coroner's Society and the Medico-Legal Society would take an early opportunity of expressing an opinion on $\mathrm{Mr}$ Troutbeck's views. 99

Troutbeck replied briefly, in The Times on 13 June, to its editorial. ${ }^{100} \mathrm{He}$ regretted that matters of purely public policy could not be discussed without the personal bias shown in the leading article and correspondence. It should be apparent to anyone of ordinary common sense that if an inquest was to be of any use it must be an independent inquiry,

\footnotetext{
97 Ibid., pp. 13-14.

98 'The Coroner as Inquisitor', Br. med. J., 1908,
} i: $1441-2$.

\footnotetext{
99 Lancet, 1908, i: 1790 . The interview, a whole column long, appeared in the Daily Telegraph, 15 June 1908, p. 13.

100 The Times, 13 June 1908, p. 6.
} 


\section{Zuck}

and the sole object of the procedure to which such exception was taken was to render it independent. The idea that there was any intention to cast a slur on the medical profession was ridiculous; on several occasions he had held an inquest in order to protect a doctor against unjust and unreasonable complaint. In this case the informant had been the Registrar of Deaths. The medical superintendent of the hospital had supplied particulars; he had been summoned as a witness but did not attend. The name of the general practitioner was not given to him until he was in court. ${ }^{101} \mathrm{He}$ did not propose to comment on continued mis-statements originally made in 1903 and repeated in other letters. He had refuted them all in his letter to the Lord Chancellor of 16 September of that year.

This last reference really put the cat among the pigeons. In a long letter published in The Times on 19 June, Dr Henry Davy, President of the British Medical Association, went over the whole ground of the 1903 complaint, item by item, yet again; ${ }^{102}$ but Troutbeck had now referred to a letter of September 1903. The Association had been left in ignorance of such a letter until now. A thorough inquiry was called for, and the question should arise whether machinery should be created for exercising a more effective supervision over the procedure of coroners. In the meantime, the British Medical Association, numbering some 21,000 medical practitioners, highly appreciated the weighty assistance that The Times had given towards the reform of Mr Troutbeck's Court.

Apart from the helpful suggestion from a "A Barrister" that the Registrar General could solve the whole difficulty by issuing a simple circular bidding the registrars not to act upon Mr Troutbeck's instruction that all cases in which the word "operation" appeared on the death certificate be referred to him, ${ }^{103}$ and two further long editorials in the next two issues of the British Medical Journal, ${ }^{104}$ there the matter rested, until the following year, when the Journal took its last tilt at Mr Troutbeck.

This was occasioned by two inquests held by him in March 1909. ${ }^{105}$ One was on a patient of Mr Sampson Handley, a surgeon who became very well-known between the wars as a specialist in cancer surgery. The patient had been operated on for cancer of the bladder, and had died shortly afterwards. The second case was a child extremely ill with peritonitis. As there was just a possibility of saving his life, the surgeon, Mr Swainson, had operated. A 12 inch length of gangrenous bowel was found, and the child died soon after. These two inquests prompted a leading article of more than one and a half pages. ${ }^{106}$

101 Troutbeck had used this excuse before. One would have thought that had he been seriously concerned to call the patient's general practitioner his officer would have been instructed to provide all the relevant information at the time when Troutbeck was first informed of the case.

102 The Times, 13 June 1908, p. 6.

103 The Times, 19 June 1908, p. 14.

$104 \mathrm{Br}$. med. J., 1908, i: 1551, and 1585-6.

105 Br. med. J., 1909, i: 932,

106 'Mr Troutbeck as the surgeon's friend', $\mathrm{Br}$. med. J., 1909, i: 915-16. From the tone of the reports, the Journal appears to have become resigned to the extension of the coroner's jurisdiction. Both the British Medical Association and Troutbeck may have been influenced by the opinion expressed by the President of the Medico-Legal Society, the highly respected Mr Justice Walton, at a meeting held on 24 March 1908, that if death by chloroform was an unnatural death, and the coroner must hold an inquest, then it seemed to him to follow that, if the death was caused by an operation, that plainly would be an unnatural death, and there would be an inquest in every case in which a man died from an operation. To Walton the two things seemed to be on the same footing. The report of this meeting, when first published (Br. med. J., 1908, i: 747-8), omitted this part of the discussion. It was only brought to the attention of the profession nearly a year later, following publication in the Proceedings of the Medico-Legal Society (Br. med. J., 1909, i: 45-6); and the question was still being debated two years later ('Deaths after operations and the jurisdiction of the coroner', Lancet, 1910, ii: 1099). 


\section{Mr Troutbeck as the Surgeon's Friend}

It began with a survey of Mr Troutbeck's practices and pronouncements to date, all of which, continued the editorial, were not unnaturally taken to show that Mr Troutbeck, for some unknown reason, had thought fit to take up an attitude of hostility, or at least of malevolent neutrality, in regard to the profession. It went on with heavy sarcasm:

But it appears that we have been mistaken, and that the coroner for the South-West District is in reality the doctor's friend, and in particular is anxious to shield the operating surgeon from blame, and to vindicate his ways to men through the medium of the enlightened juries whom he directs.

What had Mr Troutbeck done to merit this encomium? Well, he had been pleased to express the opinion that there could be no doubt that Mr Handley had been justified in undertaking the operation in the circumstances; and in the second case also, Mr Troutbeck had come forward as the surgeon's friend, and had decided that the operation was fully justified; and in both cases the jury had obediently returned a verdict of "accidental death". The Coroner had said that these inquiries were primarily for the benefit of the public, but had been good enough to add that they were perhaps of even greater benefit to the operators, who were given this opportunity of showing that they had taken the right course. It should be a great satisfaction to them to hear a jury express approval of their efforts at a public enquiry.

It was to be feared, continued the writer, that the profession may have misconceived $\mathrm{Mr}$ Troutbeck's friendly intentions; indeed, it would seem that he had been wholly misjudged. The profession had not suspected that Mr Troutbeck was a humourist. What had been taken for the insolence of office was humour. The idea that a leading surgeon should be gratified by the approval of his work expressed by a coroner's jury was truly comic. Now that Mr Troutbeck was understood, it could be seen that the absolution gratuitously bestowed by him upon surgeons who had done their best in almost hopeless circumstances was not impertinence but friendly fun. However, it went on, surgeons might well pray to be saved from so over-zealous a friend. No surgeon would care to submit his highly skilled workmanship to the judgement of men utterly incompetent to form an opinion of its value. The article continued by warning of the danger of what we would call today defensive surgery, and concluded by proposing that only men with a medical as well as a legal training should be appointed to the office of coroner. As regards Mr Troutbeck, the profession would rather have him as an open enemy than as a friend in disguise.

\section{The Profession laughs Last}

Well, there was another side to Mr Troutbeck. He was a family man, with three children, ${ }^{107}$ he was much involved in charitable work, he had a deep interest in church music, and at the coronation of George $\mathrm{V}$ in 1911 he was one of the viola players in the orchestra in the Abbey. But the profession got him in the end. Fate struck in the following year. He developed acute appendicitis, was operated on, and made satisfactory progress for a few days. Then he suffered a relapse, and, because he always had his own special way of doing things, died on 29 February $1912 .{ }^{108}$ No inquest was held. After a memorial

107 The children's story of Westminster Abbey, by one of them, G E Troutbeck, London, Mills and Boon, pp. 253, 5/-, attracted a very favourable notice. It would make a very good Christmas present for a child, or even for an adult, the reviewer thought.

(Lancet, 1909, ii: 1600).

108 The Times, 1 March 1912, p. 11. 
service at St Margaret's, Westminster, he was cremated, and his ashes were interred at his birthplace in Cumberland. Unlike his predecessor, his passing was not noticed by the medical journals.

The effect of Troutbeck's death on Freyberger was shattering. The pathology side of his practice was devastated, to the extent that, within a week of Troutbeck's death he had to remake his will, revoking a number of bequests. He now only hoped to be able to provide for his wife, "Owing", he said, "to the unfortunate turn which my affairs have taken since the death of the late Coroner John Troutbeck whom I deeply mourn". When he died, at the age of 69, on 22 August 1934, while staying at the Buckingham Hotel, Buxton, his estate was valued at nil; and when his widow died in 1950 at the age of 90 she left less than $£ 500$.

\section{The Significance of Troutbeck's Endeavour}

This story illuminates a number of attitudes and aspects of practice in Edwardian times, social, economic, medico-political, and medico-legal. It illustrates the lay attitude to anaesthesia and surgery, and delineates the pecking order within and outside the profession; and it provides an early example of the impotence of the doctors when in conflict with the lawyers and the politicians, foreshadowing the dispute with Lloyd George over the National Insurance Act of 1911. ${ }^{109}$ The inquest held on 3 June 1908 was of very great significance. It marked the end of the autonomy of the surgeon, and the beginning of public accountability; it raised the question of informed consent, and much of the argument has a remarkably modern ring, resonating with present day discourse on a number of ethical problems.

How do we view Mr Troutbeck today? Is he the villain or the hero of the story; a paranoid lawyer, a Victorian hangover from the Barretts of Wimpole Street, or a great but forgotten reforming coroner during a period of great social ferment? He held office at a time when the coroner's function had already become involved with a number of enactments that affected the everyday lives of a large part of the population. That the correct verdict was reached was becoming increasingly important, for example to avoid unfairness to both employee and employer under the terms of the Workmen's Compensation Act of 1897; and for the purposes of the Board of Trade in railway cases, the factory inspectors under the Factory and Workshops Act, the mines inspectors in mine and collieries fatalities, government inspectors under the Explosives Act, and for the allaying of public anxiety relating to the forthcoming Cremation Bill; and for the developing speciality of epidemiology. Troutbeck himself had drawn attention to all this in his letter to the Lord Chancellor of May $1903,{ }^{110}$ and it had been the subject of other communications to the medical press. ${ }^{111}$ Hence practices that appear not to have changed much since medieval times had to be modernized. Inquests ceased to be held in Falstaffian venues, and juries began to lose their cast of rude mechanicals. The newly created London County Council became an engine of change, being required by the Public Health (London) Act of 1891 to provide and maintain proper accommodation for the holding of

109 Over the National Insurance Bill, paradoxically, Horsley found himself in conflict with that very part of the profession the defence of whose interests had brought him into conflict with Troutbeck. See Lyons, op. cit., note 51 above, pp. 181-203.
${ }^{110}$ See note 52 above.

111 'The office of coroner', Br. med. J., 1900, ii: 1794-6. 


\section{Mr Troutbeck as the Surgeon's Friend}

inquests, ${ }^{112}$ and at St Pancras a new coroner's court and mortuary had already been built. ${ }^{113} \mathrm{~A}$ long period of unease about existing procedures came to a head during the first decade of this century. In 1910 the Coroner's Law and Death Certification (Amendment) Act was introduced into the House of Commons by Sir William Collins; ${ }^{114}$ but the profession's attitude was ambiguous. While, with its public service voice, the British Medical Association was calling for improvements, it campaigned against them whenever the income of its members was threatened.

The London County Council had set the agenda, but of all the capital's coroners only Troutbeck seems to have implemented it with vigour. Clearly he must have been a very awkward customer, and certainly he could have made more effort to involve the local general practitioners; and while it is understandable that his initial expressions of regard for them as doctors would become soured by their continued antagonism, tinged with their xenophobia where Freyberger was concerned, his assertion that it must be assumed that colleagues at the same hospital would collude to conceal the cause of death was hardly likely to mend any bridges. To that extent there was a problem of personality, but there was also the economic aspect; this affected both sides, the income of the general practitioners, and Troutbeck's expenses, which were the highest of all the London districts. But he was blazing a new trail, and by his employment of "his own" pathologist, ${ }^{115}$ by his insistence on removing the body to the public mortuary, and by holding the first inquest into a surgical death, he was the originator of the system that is still occasionally grumbled about today; although nowadays we are not entirely unhappy to see the possible surgical contribution to a death being questioned, nor do doctors take umbrage when commended for their efforts by a coroner's jury.

112 Br. med. J., 1893, ii: 1246.

$113 \mathrm{Br}$. med. J., 1886, ii: 1228. Apart from a spacious courtroom, three separate mortuary rooms were provided, one for infectious cases, one for the deceased poor from the adjacent workhouse, and the third for the generat public, who were reassured that all three were entirely disconnected. The majority of the general public, of course, had an equal opportunity of ending up in any one of the three.

114 'Coroners Law and Death Certification (Amendment) Bill', Br. med. J. Supplement, 1910, ii: 90-3. The Bill dealt with the appointment of coroners, their qualifications and payment, and provided for retirement at 65 with superannuation. Coroners had to be lawyers or registered medical practitioners with a law qualification, of at least five years standing. It provided also for the appointment of medical investigators or pathologists, and it authorized the Secretary of State to frame the rules for the guidance of coroners. It laid down regulations for the certification and registration of death and burial, removed the anomalies and invitations for abuse, and prescribed what had previously been lacking, a standard form of death certificate.

The Bill was received critically by the British
Medical Association. ('Coroner's law and death certification’, Br. med. J., 1910, ii: 98-100. See also Br. med. J., 1910, ii: 1732 , and 'The Coroners Act and the need for amendment', Br. med. J., 1913, i: 889-91). Its proposals were compared unfavourably with the situation in Scotland, where the Procurator Fiscal had a much freer hand as regards medical costs. There was no provision for payment for the completion of a death certificate, and why should a legal qualification be required of a doctor when no proof of even an elementary knowledge of medicine was required of a lawyer? There was much agitation against the Bill among the general practitioners, the Association campaigned against it, and it did not receive the support of the Home Secretary, Winston Churchill. An amended Bill was introduced in 1914 (Br. med. J., 1914, i: 783), but a new Act was not passed until 1926.

115 According to the Independent on Sunday, 23 May 1993, p. 4, if, after the death of Beverly Allitt's first victim, the Grantham coroner, strangely coming full circle, had ordered a special post-mortem examination by a paediatric pathologist, she might have been stopped at once. 